\title{
ANAEROBIC BACTERIA IN MILK AND SOME DAIRY PRODUCTS WITH SPECIAL REFERENCS TO STORMY FERMENTER SPECIES
}

\author{
*Al-Ashmawy, Maha, A.; El-Toukhy, Marwa, I.
}

*Food Hygiene and Control Dept., Fac. of Vet. Med., Mansoura University.

\begin{abstract}
A total of one hundred random samples of raw milk, milk powder, baby food, processed cheese and Ras cheese (20 samples each) were collected from different shops and supermarkets in Mansoura city to be examined for stormy fementer Clostridia species.

The incidence of stormy fermenter Clostridia was 15\%, 40\%, 50\%, $75 \%$ and $30 \%$ in examined raw milk, milk powder, baby food, processed cheese and Ras cheese samples respectively. while the mean count was $43.67 \pm$ S.E. $14.2 / \mathrm{ml}$ raw milk, $25.50 \pm$ S.E. $4.45 / \mathrm{ml}$ of reconstituted milk powder,28 \pm S.E.3.13/g processed cheese and 14.16 \pm S.E. $2.58 / \mathrm{g}$ of rass cheese samples respectively.

The isolated strains from raw milk samples were identified as C.perfringens (100\%) while the isolated orgamisms from milk powder were six strains of C.perfringens (75\%)and two strains of C.butyricum (25\%).The isolated Clostridia from baby food were identified as C.perfringens (70\%) and C.butyricum (30\%) while from processed cheese were identified as C.perfringens (46.7\%), C.butyricum (33.3\%), C.septicum (13.3\%) and C.chauvoei (6.7\%).

Three strains of C.perfringens (50\%) and one strain of each C.butyricum (16.7\%), C.septicum (16.7\%) and C.sphenoides (16.7\%) were detected in the examined Ras cheese samples.

The public health and economic importance of isolated Clostridia spp. as well as recommendation for preventing and minimizing the microbial contamination of dairy products were also discussed.
\end{abstract}




\section{INTRODUCTION}

Milk and its products are highly nutritious food for the growth and multiplication of pathogenic and spoilage bacteria such as Clostridia organisms.

Clostridia are widely distributed in nature but they seem to have two principle habitats, the soil and the intestine of man and animals. Frequently, they appear in dust, milk and sewage. The presence of Clostridia in milk has been a matter of public health concern since the early days of dairy industry because of their ability to produce a wide diversity of biologically active proteins, many of which have roles in provoking human, animal diseases and cause food deterioration.

The stormy fermenter Clostridia species as the group which capable of fermenting milk lactose into lactic acid with extreme gas production without digestion of casein (milk clot) such as C.perfringens, C.butyricum, C.baratii, C.sphenoides, C.septicum and C.chauvuei.

The most important one in this group is Clostridium perfringens which produces an enterotoxin that causes food poisoning outbreaks after the ingestion of highly contaminated food with large number of vegetative organisms. This enterotoxin is produced in the intestine during sporulation of vegetative cell reacting with the receptors on the surface of intestinal epithelial cells leading to tissue damage and accumulation of fluids in the intestinal lumen (Mcclane,1992) giving the apparent clinical sign of bloody diarrhea.

Clostridium butyricum was the first known anaerobic organism (Pasteur,1861 ${ }^{\mathrm{a}, \mathrm{b}}$ and Willis,1969). It has been considered non pathogenic(Willis,1990); however, neurotoxigenic strains have been implicated as the cause of two cases of type-E infant botulism (Aureli 
and Fenicia,1986), while Clostridium baratii produces a type F-like botulism neurotoxin that has been involved in number of human cases of botulism.

Besides the public health hazards, Clostridia have a profound economic impact on the dairy industry. For instance, the resistance of Clostridia to pasteurization temperature in cheese milk then their survival along with the manufacture steps including ripening and ending with the storage give Clostridia a special importance.

From the economic point of view Clostridia can release lactose enzyme which ferments lactose into lactic acid and gas; leading to the development of holes that will be situated deeply in cheese blocks, these holes may coalesce to form a network leaving a hallow core inside the cheese blocks. Also, the released gas may result in the expansion of the preexisting mechanical holes deliberately during cheese manufacture, these openings will be accompanied with stinking odor in old cheese rendering the final product impossible to be sold in markets and returning the cheese back to the producer with major drop in individual financial income and great economic losses.

As milk and its products represent potential hazardous source of Clostridia species which not only threatened the public health but also have a great economic effect on the dairy industry so this work was conducted to isolate and identify Clostridia spp. in milk and some dairy products especially stormy fomenter species and mainly based on looking for the Clostridia organisms spores which resist some food preservation methods such as pasteurization and chilling. These organisms have spores which could germinate into developed cells resulting in foul odour and late gas blowing defects especially in cheese manufacture leading to drop in individual and economic income. 


\section{MATERIAL AND METHODS}

One hundred random samples of milk and milk products including raw milk, milk powder, baby food, processed cheese and Ras cheese (20 samples each) were collected from mansoura city markets. The samples were collected in clean, dry and sterile containers then transferred to the laboratory as soon as possible to be examined.

Preparation of decimal dilutions from the examined samples $\boldsymbol{A P H A}$ (1992)

\section{1) Stormy fermentation test (Cruckshank et. Al.,1969):}

\section{a- Milk, milk powder and baby food samples:}

Ten mls of milk, reconstituted milk powder and baby food samples were added to test tubes and heated in the water bath adjusted at $80^{\circ} \mathrm{C}$ for 30 minutes. Tubes were sealed with paraffin wax and incubated at $37^{\circ} \mathrm{C}$ for five days. The torning of paraffin layer with the appearance of flocculatent or clot with translucent fluid (without the digestion of milk clot or curd) was considerd a positive result.

\section{b- Cheese samples:}

One $\mathrm{ml}$ of the prepared cheese samples was inoculated into sterile test tubes containing $10 \mathrm{ml}$ of sterile skim milk and heated in the water bath adjusted at $80^{\circ} \mathrm{C}$ for 30 minutes then sealed with paraffin wax followed by incubation at $37^{\circ} \mathrm{C}$ for five days and the obtained positive result was as before.

\section{2) Enumeration of Clostridia spores using Most Probable Number (MPN) (Diane et.al.,1995):}

Serial dilutions were made from $10^{-1}, 10^{-2}$ and $10^{-3}$ dilutions was inoculated into three replicate tubes of Reinforced Clostridial broth medium(RCM). The inoculated tubes were incubated anaerobically in 
Gas Pak system using gas generator envelopes(carbon dioxide and hydrogen gases) at $37^{\circ} \mathrm{C}$ for $48 \mathrm{hrs}$. The positive result was represented the black tubes.

The MPN of Clostridia/ml or $\mathrm{g}$ of each sample was calculated according to statistical tables(Diane et. Al.,1995).

\section{3) Isolation of Clostridia spores from the examined samples:}

A loopful from each of the previously prepared sample which showed positive stormy fermentation was streaked onto the surface of $\mathrm{RCM}$ plates then the plates were incubated anaerobically at $37^{\circ} \mathrm{C} / 48 \mathrm{~h}$. and five black colonies were picked up and inoculated into freshly boiled and cooked meat broth tubes. The inoculated tubes were incubated anaerobically at $37^{\circ} \mathrm{C} / 48 \mathrm{~h}$. to apply the biochemical tests.

\section{4) Identification of Clostridia isolates:}

The isolated organisms were identified according to Toply and Wilson's (1998).

\section{RESULTS AND DISCUSSION}

Table (1): Incidence of stormy fermentation in the examined samples.

\begin{tabular}{||l||c||c|c||}
\hline \multirow{2}{*}{$\begin{array}{c}\text { Types of } \\
\text { examined samples }\end{array}$} & $\begin{array}{c}\text { Total No. of } \\
\text { samples }\end{array}$ & $\begin{array}{c}\text { stormy fermentation } \\
\text { No. of positive } \\
\text { samples }\end{array}$ & $\begin{array}{c}\text { \% of positive } \\
\text { samples }\end{array}$ \\
\cline { 3 - 4 } Raw milk & 20 & 3 & 15 \\
Milk powder & 20 & 8 & 40 \\
Baby food & 20 & 10 & 50 \\
Processed cheese & 20 & 15 & 75 \\
Ras cheese & 20 & 6 & 30 \\
\hline \hline Total & $\mathbf{1 0 0}$ & $\mathbf{4 2}$ & $\mathbf{4 2}$ \\
\hline
\end{tabular}

P.value $=0.002$

chi-value $=16.667$

$\overline{\text { Kafrelsheikh Vet. Med. J. Vol. } 6 \text { No. } 2 \text { (2008) }}$ 
Table (2): Statistical analysis of Clostridia in examined samples:

\begin{tabular}{||l||c|c||c|c|c||}
\hline \multirow{2}{*}{ Type of samples } & \multicolumn{2}{|c|}{ Positive samples } & \multicolumn{3}{c||}{ Count(MPN/g or ml) } \\
\cline { 2 - 6 } & No. & $\%$ & Min. & Max. & Mean \pm S.E. \\
\hline \hline Raw milk & 3 & 15 & 21 & 70 & $43.67 \pm 14.2 \mathrm{a}$ \\
Milk powder & 8 & 40 & 11 & 40 & $25.50 \pm 4.45 \mathrm{~b}$ \\
Baby food & 10 & 50 & 9 & 40 & $23.30 \pm 3.89 \mathrm{~b}$ \\
Processed cheese & 15 & 75 & 9 & 40 & $28.00 \pm 3.13 \mathrm{~b}$ \\
Ras cheese & 6 & 30 & 7 & 23 & $14.16 \pm 2.58 \mathrm{~b}$ \\
\hline \hline
\end{tabular}

No \& $\%$ of positive stormy fermentation samples.

Means with the same letter are not significantly different at 0.05 .

Table (3): Clostridia species isolated from the examined samples.

\begin{tabular}{|c|c|c|c|c|c|c|c|c|c|c|c|c|}
\hline \multirow{3}{*}{$\begin{array}{l}\text { Type of } \\
\text { isolates }\end{array}$} & \multicolumn{10}{|c|}{ The examined samples } & & \\
\hline & \multicolumn{2}{|c|}{ Raw milk } & \multicolumn{2}{|c|}{$\begin{array}{c}\text { Milk } \\
\text { powder }\end{array}$} & \multicolumn{2}{|c|}{ Baby food } & \multicolumn{2}{|c|}{$\begin{array}{c}\text { Processed } \\
\text { cheese }\end{array}$} & \multicolumn{2}{|c|}{$\begin{array}{l}\text { Rass } \\
\text { cheese }\end{array}$} & \multicolumn{2}{|c|}{ Total } \\
\hline & No. & $\%$ & No. & $\%$ & No. & $\%$ & No. & $\%$ & No. & $\%$ & No. & $\%$ \\
\hline C.butyricum & - & - & 2 & 25 & 3 & 30 & 5 & 33.3 & 1 & 16.7 & 11 & 26.2 \\
\hline C.chauvoei & - & - & - & - & - & - & 1 & 6.7 & - & - & 1 & 2.4 \\
\hline C.perfringens & 3 & 100 & 6 & 75 & 7 & 70 & 7 & 46.7 & 3 & 49.9 & 26 & 61.9 \\
\hline C.septicum & - & - & - & - & - & - & 2 & 13.3 & 1 & 16.7 & 3 & 7.1 \\
\hline C.sphenoides & - & - & - & - & - & - & - & - & 1 & 16.7 & 1 & 2.4 \\
\hline Total & 3 & 100 & 8 & 100 & 10 & 100 & 15 & 100 & 6 & 100 & 42 & 100 \\
\hline
\end{tabular}

The results given in Table (1) declare that the stormy fermenter Clostridia were found in 3(15\%) examined raw milk samples and according to the table(2), C.perfringens was the only Clostridia from these examined three samples with a mean count of $43.67 / \mathrm{ml}$. The milk can be contaminated with Clostridia through the teat which in turn may be contaminated from various sources such as the soil, animal bedding, feaces or low quality silage fed to the lactating animal. All the previous 
sources combined with the lack of sanitary practices during milking can contribute to the spoilage of raw milk with Clostridia; as the spore former Clostridia associated with the teat move up the teat canal into the interior of the udder and gain entrance to the milk (Olson and Mocquot, 1980).

Also, the given data in Table(1) show that the stormy fermenter Clostridia were present in $8(40 \%)$ of the examined dry milk samples while in case of baby food they were found in 10(50\%) of the examined samples with a mean count of $25.50 / \mathrm{ml}$ reconstituted milk powder and with a mean count of $23.30 / \mathrm{ml}$ of reconstituted baby food (table,2).

According to Table(3), C.perfringens and C.butyricum were isolated from $75 \%$ and $25 \%$ of the examined dried milk samples and from $70 \%$ and $30 \%$ of examined baby food samples respectively.

Clostridia are among the few species of bacteria that had been reported as the naturally occurring microflora in dry milks(Elmmer and James, 1998). The dry milks such as milk powder and baby food can be contaminated with Clostridia either for processing from low quality raw milk with high Clostridia load or post processing from an air born source due to improper sealing of the packages.

Stormy fermenter Clostridia were also detected in 15(75\%) of the examined processed cheese samples and in 6(30) of the examined rass cheese samples(Table,1). The Clostridia were detected with mean count of 28/g processed cheese and with a mean count of 14.16/g in hard ras cheese(table,2).

According to table(30, the isolated Clostridia were identified as C.perfringens $\quad(46.7 \%, \quad 49.9 \%) ; \quad$ C.butyricum(33.3\%, 16.7\%); C.septicum $(13.3 \%, 16.7 \%)$ from both processed cheese and hard rass 
cheese respectively, while C.chauvoei was isolated only from processed cheese in $6.7 \%$ and C.sphenoid was isolated from $16.7 \%$ of hard rass cheese.

The contamination of cheese with Clostridia depends on the initial amount of Clostridia spores exist in cheese milk intended for cheese manufacture, the impurity of starter and finally on the ability of Clostridia organisms to grow under the conditions of processing such as $\mathrm{pH}$, salt, temperature and moisture; as during cheese maturation, the change in the environmental conditions may allow the growth of initially inhibited contaminants (Elmer and james, 1998).

Using high quality raw milk for the manufacturing of milk powder, baby food, processed cheese and Ras cheese; proper cleaning and sanitization of allequipment; employment only healthy workers with health certificate in dairy industry; effectiveness of sanitation program in dairy farms and dairy plants must be periodically monitored on routine basis; educational programs of proper hygiene practices should be imposed and the concerned authorities should take an active part in the control of dairy industry, are considered as recommendations should be undertaken to prevent contamination of milk and other dairy products by Clostridia organisms.

\section{REFERENCE}

- American Public Health Association (A.P.H.A) (1992): Standard methods for examination of dairy products. I.N.C., $16^{\text {th }}$ Ed. Washington D.C., USA.

- Aureli,P.and Fenicia,L.(1986): Two cases of type -E infant botulism caused by neurotoxigenic Clostridium butyricum in Italy. J. Infec. Dis., 154:201-6. 
- Cruckshank,R.;Duguid,J.P. and Swain,R.H. (1969): Medical microbiology 11Ed.E.S Livingston Limited Edenburgh. London, cited after Nahed, (1997).

- Diane,R.; William,H. and Melody,G.(1995): Practical Food Microbiology, $2^{\text {nd }}$ Ed., by The Public Health Laboratory Service London.

- Elmer,H.M. and James,L.S.(1998): Applied Dairy Microbiology. Marcel Dekker, Inc., New York, USA.

- Olson.J.C; Mocquot,G.(1980): Milk and Milk products. In: International Commission on Microbiological specifications for foods. Microbial Ecology of foods. Food Commodities Vol.2. NewYork: Academic press. 1980, P:470.

- Pasteur,L. (1861 $\left.{ }^{\mathrm{a}}\right)$ : Animalcules infusores vivant sans gas oxygen libre et determinant des fermentations, CR Acad.Sci. Paris, 52:344-7. cited after Toply and Wilson(1998).

- Pasteur,L. $\left(1861^{\mathrm{b}}\right)$ : Experiences et vues nouvelles sur la nature des fermentations, CR Acad.Sci. Paris, 52:1260-4 cited after Toply and Wilson(1998).

- Toply and Wilson (1998): Toply and Wilsons' Microbiology and Microbial Infections, $9^{\text {th }}$ Ed., Vol.2, by Arnold-London.

- Willis, A.T. (1969): Clostridia of wound infection, Butterworths, London. cited after Toply and Wilson(1998).

- Willis, A.T. (1990): Clostridium the spore bearing anaerobe, Toply and willsons' Principles of Bacteriology, Virology and Immunology. $8^{\text {th }}$ edn, eds Parker MT, Collier L II, Arnold, London, 211-46. 


\section{البكتريا اللاهو ائية في اللبن و بعض منتجات الألبان و خاصة الأجناس موجبة عاصفة التخمر}

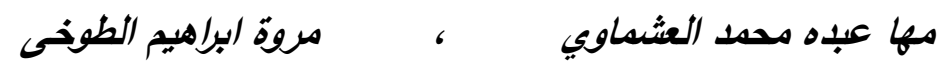 \\ قسم الرقابة الصحية على الأغذية - كلية الطب البيطري - جامعة المنصورة}

أجريت الدراسة على مائة عينة ( عشرون عينة لكل من اللبن الخام، اللبن المجف،، غذاء

الأطفال، الجبن المطبوخ و الجبن الراس"الجبن الرومي" ) و التي تم تجميعها من مصادر مختلفة بمحافظة الدقهلية و قد أجريت الدراسة لتحديد مدى تواجد عترات ميكروب الكولستيريديا موجبة عاصفة التخمر في العينات الني نم فحصها و قد دلت النتائج على تواجد ميكروب الكولستيريديا Clostridia في 15\%30\%، 50\%، 75\%، 30\% من عينات اللبن الخام، اللبن المجف، غذاء الأطفال، الجبن المطبوخ و الجبن الراس"الجبن الرومي" على التوالي.

وجاء منوسط العدّ التقريبي 43.67ميكروب/ملى من اللبن الخام، 25.50/جم من اللبن المجفف، 23.30/جم من غذاء الأطفال، 28/جم من الجبن المطبوخ و 14.16/جم من الجبن الرومي. وقد تمّ عزل ميكروب الكلوستريديا Clostridia بنسبة(42\%) من العينات وتبين أن عترة الكلوستريديم بيرفرنجنس C.perfringens هى الأكثر تواجداً (61.9\%)، يليها الكلوستريديم بيوتريكم

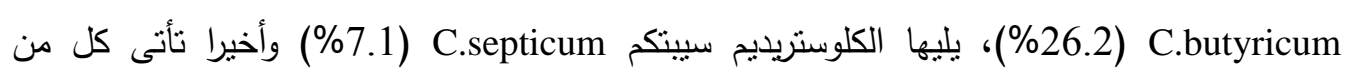
الكلوستريديم شوفياى C.chauvaei و الكلوستريديم سفينويد C.sphenoides (2.4\%). هذا وقد نم مناقتشة النتائج من الناحيتين الصحية و الاقتصادية وكذللك الاقتراحات والتوصيّات الواجب اتخاذها أثثاء عمليات الإنتاج، التصنيع، التخزين والتداول وذلك لحماية المستهلك وحفاظا 